Report No. 25

\title{
Weld and Heat Affected Zone Crack Arrest Fracture Toughness of AAR TC128 Grade B Steel
}

George E. Hicho
Donald E. Harne

U.S. DEPARTMENT OF COMMERCE Technology Administration National Institute of Standards and Technology

Materials Science and

Engineering Laboratory

Metallurgy Division

Gaithersburg, MD 20899
U.S. DEPARTMENT OF COMMERCE Rockwell A. Schnabel, Acting Secretary NATIONAL INSTITUTE OF STANDARDS AND TECHNOLOGY

John W. Lyons, Director 

Report No. 25

\section{Weld and Heat Affected Zone Crack Arrest Fracture Toughness of AAR TC128 Grade B Steel}

George E. Hicho
Donald E. Harne

U.S. DEPARTMENT OF COMMERCE Technology Administration National Institute of Standards and Technology

Materials Science and

Engineering Laboratory

Metallurgy Division

Gaithersburg, MD 20899

February 1992

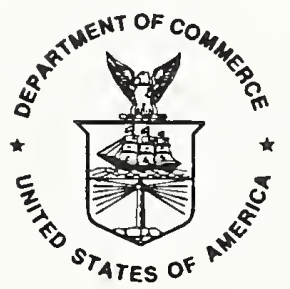

U.S. DEPARTMENT OF COMMERCE Rockwell A. Schnabel, Acting Secretary NATIONAL INSTITUTE OF STANDARDS AND TECHNOLOGY

John W. Lyons, Director 



\title{
WELD AND HEAT AFFECTED ZONE \\ CRACK ARREST FRACTURE TOUGHNESS \\ OF AAR TCl28 GRADE B STEEL
}

George E. Hicho and Donald E. Harne

\author{
Mechanical Properties and Performance Group \\ Metallurgy Division \\ National Institute of Standards and Technology \\ Gaithersburg, MD 20899
}

\section{ABSTRACT}

Weld and heat affected zone (HAZ) crack arrest fracture toughness tests was conducted on specimens from welded plates of normalized AAR TC128 grade B steel, currently used in appropriate tank cars that carry hazardous materials. The plates were joined under laboratory conditions and stress relieved using the recommended Association of American Railroads (AAR) welding procedures. In the calculation of the crack arrest fracture toughness, the yield strength at the test temperature is required in the appropriate equations. Hence weld metal tensile specimens were prepared from the joined plates and tested at temperatures ranging from $-51{ }^{\circ} \mathrm{C}$ to $-18{ }^{\circ} \mathrm{C}$. Weld and HAZ crack arrest fracture toughness specimens were prepared and tested at $-51{ }^{\circ} \mathrm{C}$. Because of enhanced weld toughness, it was impossible to initiate a crack in any of the weld specimens tested, hence a crack arrest fracture toughness was not obtained. Crack arrest fracture toughness tests were conducted on similar specimens where the crack plane was withir the HAZ. Crack arrest fracture toughness values were obtained for specimens tested at $-51{ }^{\circ} \mathrm{C}$ and at $-18{ }^{\circ} \mathrm{C}$. Specimens tested at $-29{ }^{\circ} \mathrm{C}$ were not valid since the final crack length could not be determined. Crack arrest fracture toughness results indicated that both the weld metal and the HAZ for the welded normalized and stress relieved AAR TC128 grade B steel were highly resistant to crack initiation and possessed the ability to arrest a propagating crack.

\section{INTRODUCTION}

The welds tested in this study joined steel plates that are currently used in appropriate tank cars that carry hazardous commodities. The traditional mechanical properties and fracture toughness determined for AAR TC128 grade B steel in both the normalized, and normalized and stress relieved conditions were presented in a paper entitled, "Mechanical Properties and Fracture Toughness of AAR TC128 grade B Steel in the Normalized, and Normalized and Stress Relieved Conditions" by Hicho and Harne. In that paper crack initiation and crack arrest fracture toughness, as a function of temperature, were determined for base plate material. To compliment this work, the crack arrest fracture toughness of the 
weld metal and heat affected zone were evaluated. This paper will show the ability of the weld metal and the associated heat affected zone to arrest a propagating crack.

\section{MATERIAL AND WELDING PROCEDURE}

Six plates, $1.4 \mathrm{~cm}$ ( $9 / 16$ inch) in thickness by $28 \mathrm{~cm}$ (11 inches) in width, and $91 \mathrm{~cm}$ (36 inches) in length, of normalized AAR TC128 grade B steel were sent to Union Tank Car Company (UTC) to be welded and stress relieved by $\mathrm{Mr}$. D. Untermeyer of UTC. The welding procedures followed by Mr. Untermeyer and the UTC staff are detailed in Appendices I and II. The plates were returned to the National Institute of Standards and Technology and test specimens were prepared.

\section{TEST PROGRAM}

Tensile specimens taken from the weld metal were prepared in order to evaluate the mechanical properties as a function of test temperature. Of primary importance is the yield strength since it is used in the determination of the crack arrest fracture toughness. American Society for Testing and Materials (ASTM) tensile specimens with a reduced diameter of $6.4 \mathrm{~mm}$ ( 0.25 inch) were machined from the centerline of the weld according to ASTM Method A 370-90. The tensile specimens were tested at $-51{ }^{\circ} \mathrm{C}\left(-60^{\circ} \mathrm{F}\right),-40{ }^{\circ} \mathrm{C}\left(-40{ }^{\circ} \mathrm{F}\right),-29^{\circ} \mathrm{C}\left(-20{ }^{\circ} \mathrm{F}\right)$, and $-18{ }^{\circ} \mathrm{C}\left(0{ }^{\circ} \mathrm{F}\right)$ in an environmental chamber where the temperature was held to $\pm 2{ }^{\circ} \mathrm{C}$. Knoop hardness tests were conducted on the crack arrest specimens after testing. The specimens were sectioned, polished, etched, and Vickers hardness measurements taken. The Vickers measurements were then converted to Rockwell B hardness values. Metallographic examinations were also conducted on the etched microstructures and representative photomicrographs were taken. Crack arrest specimens were prepared and tested according to ASTM Method 1221-90. Two types of crack arrest specimens were prepared; one where the crack plane was entirely within weld metal, and the other where the crack plane was along the heat affected zone. Photomicrographs were used as an aid to locate the HAZ. Crack arrest testing was initiated at $-51{ }^{\circ} \mathrm{C}\left(-60^{\circ} \mathrm{F}\right)$ since this temperature corresponded to the lowest expected service test temperature to which this tank car steel would be exposed.

\section{RESULTS}

\section{Tensile Tests}

The results of the weld metal tensile tests are shown in Table 1 and figure 1. The yield strength was found to be essentially independent, $545 \mathrm{MPa}$ ( $80 \mathrm{ksi}$ ), from $-18{ }^{\circ} \mathrm{C}\left(0{ }^{\circ} \mathrm{F}\right)$ to $-51{ }^{\circ} \mathrm{C}\left(-60^{\circ} \mathrm{F}\right)$. The yield strength of the base plate was found to increase as the test temperature decreased and reach a value of about $450 \mathrm{MPa}(65 \mathrm{ksi})$ at $-51^{\circ} \mathrm{C}\left(-60^{\circ} \mathrm{F}\right)$. This improved yield strength for the weld material is beneficial. It has been shown that as the temperature decreases, as in the base plate, the yield strength decreases. This increase in yield strength is often accompanied by a decrease in material toughness. However as noted in the all weld metal mechanical property test results, the yield strength was essentially uniform over the comparable test temperatures. This leads to improved toughness properties where the weld is tougher, i.e., more resistant to 
crack initiation than the base plate. The toughness, in terms of the reduction in area and elongation, was comparable to base plate material.

\section{$\underline{\text { Hardness }}$}

Vickers hardness measurements were taken in the welds and the heat affected zones of selected etched specimens. The results, and the corresponding hardness in Rockwell B units, are shown in Table 2. They indicate that the weld metal and base metal are within allowable limits. The hardness of the heat affected zone was also within acceptable limits; that is, there was no indication of hard, brittle zones which might lead to unstable cleavage fracture.

\section{Crack Arrest Tests}

In crack arrest testing, in order to obtain a valid crack arrest fracture toughness, one of the primary requirements for test validity is that a crack must initiate, propagate, and then arrest in the test specimen. Unlike other fracture toughness tests, a preexisting crack is not fatigued in these crack arrest specimens. Instead, a hard, brittle weld is deposited in the region where the crack is desired to initiate. On the application of a load, a crack is supposed to initiate in this hard, brittle zone and propagate into the weld metal and arrest. To enhance the initiation, the temperature is reduced to where the yield strength is increased and the toughness is reduced.

Tests were begun at $-51{ }^{\circ} \mathrm{C}\left(-60^{\circ} \mathrm{F}\right)$, and we were unable to initiate a crack in the all weld metal specimen. The test was repeated five more times, and on each occasion we were unable to initiate a crack in the specimen. Hence, we concluded that the weld metal was very resistant to crack initiation and had a higher crack initiation value than the base plate material. This further indicated that if a crack initiated in the base plate, it would not propagate in the weld metal since the weld metal was more resistant to both crack initiation and propagation.

Specimens were prepared to determine the crack arrest toughness of the heat affected zone. This is the zone adjacent to the weld and a photomicrograph of several heat affected zones are shown in figures 2 to 6 . Crack arrest tests were also conducted at $-51{ }^{\circ} \mathrm{C}\left(-60^{\circ} \mathrm{F}\right)$ and arrest $\mathrm{K}_{\mathrm{a}}$ 's of 48 and $69 \mathrm{MPa} \times \mathrm{M}^{1 / 2}$ (44 and $\left.63 \mathrm{Ksi} \times \mathrm{in}^{1 / 2}\right)$ were obtained. The arrest $\mathrm{K}^{\prime} \mathrm{s}$ were equivalent to the arrest $\mathrm{K}^{\prime} \mathrm{s}$ obtained for the base metal. Similar tests were conducted at $-29{ }^{\circ} \mathrm{C}\left(-20^{\circ} \mathrm{F}\right)$ and it was not possible to obtain a crack arrest value since we believe that because of the variance in the microstructure of the HAZ, the propagating crack jumped out of the side groove. Hence we were not able to obtain a final crack length and a crack arrest value. At $-18^{\circ} \mathrm{C}\left(0{ }^{\circ} \mathrm{F}\right)$, a crack arrest value of 156 $\mathrm{MPa} \mathrm{M}^{1 / 2}\left(172 \mathrm{Ksi} \times \mathrm{n}^{1 / 2}\right)$ was obtained. Compared to other crack arrest values, this value is very high. All of these crack arrest results indicate that both the weld metal and HAZ possess the ability to arrest a propagating crack. Hence under these laboratory conditions, the results indicate that in the presence of a crack, both the weld metal and the HAZ would be highly resistant to catastrophic failure. 


\section{Metallographic Examinations}

Photomicrographs of the crack arrest test specimens are shown in figures 2 to 6 . The microstructures of all the welds were similar. At higher magnification coarse dendritic structure, characteristic of welded material, was observed. The stock molbydate etchant was composed of $100 \mathrm{ml}$ water, $100 \mathrm{ml}$ nitric acid, and 15 grams ammonium molybdate. When used, $1 \mathrm{ml}$ of ethyl alcohol was added to the stock solution.

\section{Conclusions}

The welds examined in this study were prepared using laboratory conditions. The results clearly indicate that the welds and the heat affected zone adjacent to these welds possessed fracture toughness properties that inhibited crack initiation and propagation.

\section{ACKNOWLEDGEMENT}

This work was supported by the Federal Railroad Administration and monitored by Ms. Claire Orth, Chief of the Safety Research Division. We would also like to thank Mr. M. Untermeyer and his staff of Union Tank Car Company for welding the test plates. 
Table 1. Tensile Test Results for all Weld Metal Specimens.

\begin{tabular}{|c|c|c|c|c|c|c|c|c|}
\hline Specimen & Test & Temp. & \multicolumn{2}{|c|}{ UTS } & \multicolumn{2}{|c|}{ Ys $(0.2 \%)$} & $\mathrm{R}_{\mathrm{A}}$ & Elongation, \% \\
\hline W1 & -51 & -60 & 694.5 & 100.8 & 556.0 & 80.7 & 59.2 & 29.7 \\
\hline W2 & -51 & -60 & 689.7 & 100.1 & 546.4 & 79.3 & 63.1 & 24.4 \\
\hline W3 & -40 & -40 & 697.9 & 101.3 & 555.3 & 80.6 & 64.5 & 30.7 \\
\hline W4 & -29 & -20 & 684.9 & 99.4 & 550.5 & 79.9 & 64.0 & 28.9 \\
\hline W5 & -18 & 0 & 673.2 & 97.7 & 541.6 & 78.6 & 64.8 & 31.4 \\
\hline
\end{tabular}

Table 2. Knoop and Corresponding Rockwell B (HRB) Hardness Results for Base Metal, Heat Affected Zones, and Weld Metal

\begin{tabular}{|c|c|c|c|c|c|c|}
\hline \multirow{2}{*}{$\begin{array}{l}\text { Specimen } \\
\text { Code }\end{array}$} & \multicolumn{2}{|c|}{ Base ${ }^{1}$} & \multicolumn{2}{|c|}{ Heat Affected } & \multicolumn{2}{|c|}{ Weld } \\
\hline & Metal & $(\mathrm{HRB})$ & Zone & (HRB) & Metal & (HRB) \\
\hline $1 / 2 \mathrm{~A}$ & 159.7 & 83 & 168.3 & 86 & 203 & 90.5 \\
\hline $1 / 2 \mathrm{~B}$ & 156.3 & 82 & 173.3 & 87 & 206.3 & 94.0 \\
\hline $1 / 2 C$ & 160.0 & 83 & 169.0 & 86 & 192.0 & 91.5 \\
\hline $1 / 2 \mathrm{D}$ & 163.3 & 84 & 167.6 & 85.5 & 195.6 & 92.0 \\
\hline $1 / 2 \mathrm{E}$ & 159.3 & 83 & 176.6 & 88.0 & 202.6 & 93.0 \\
\hline
\end{tabular}

1 Average of three values 



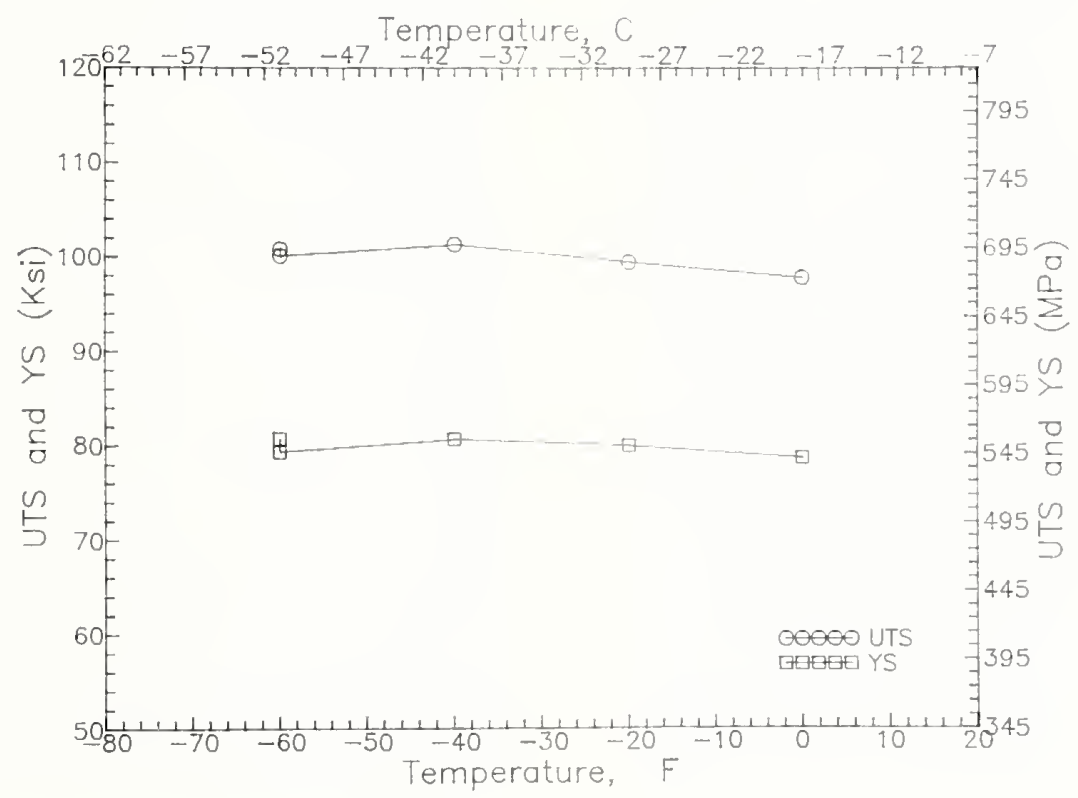

Figure 1. Tensile test results for all weld specimens. 



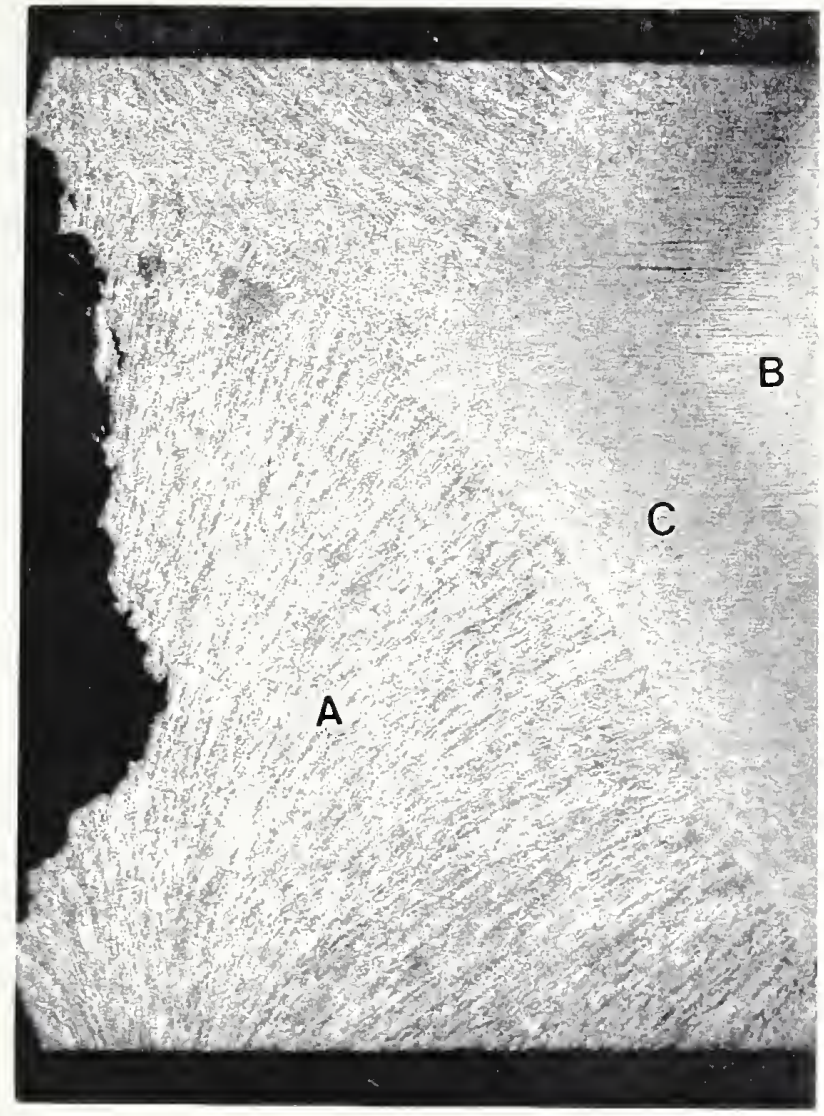

(a)

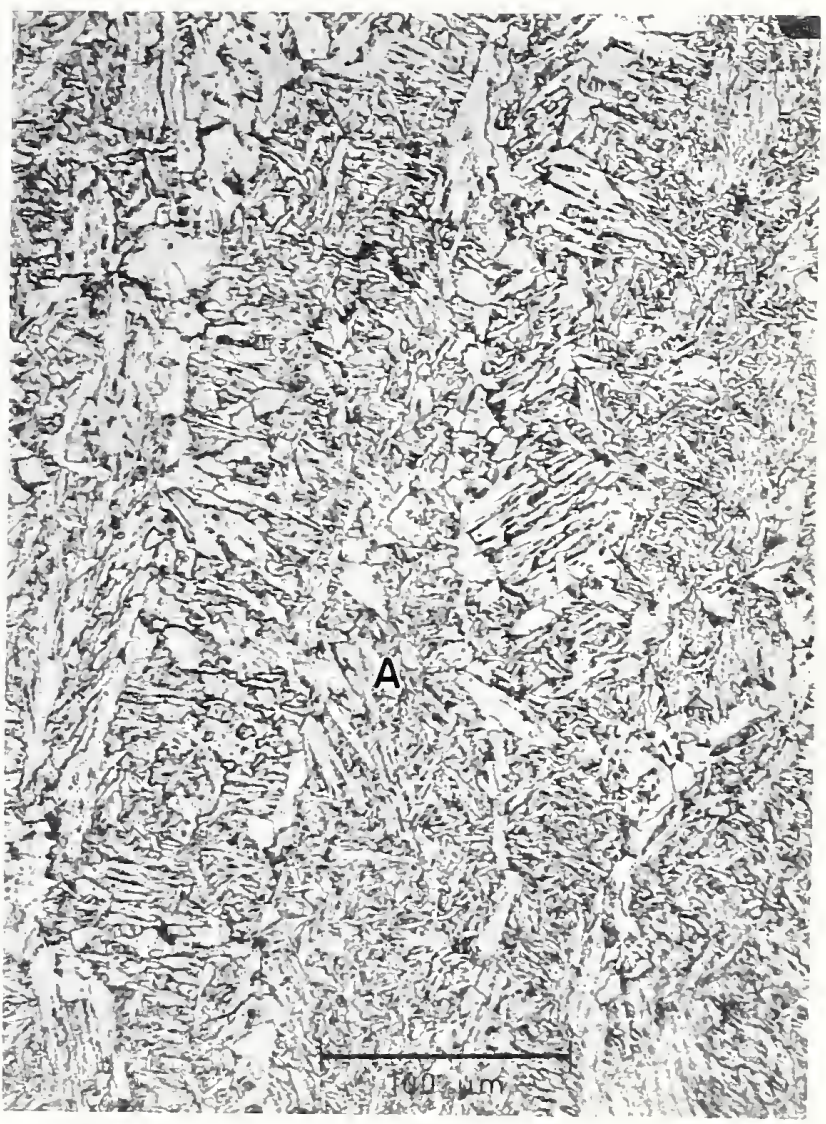

(b)

Figure 2. Photomicrographs showing the microstructure of the weld metal in specimen $1 / 2 \mathrm{~A}$. The microstructure consists of ferrite and pearlite. The weld metal is A, base metal, B; and the HAZ $C$.

Mag: a) X6.5, b) X250 Etchant: Molybdate 



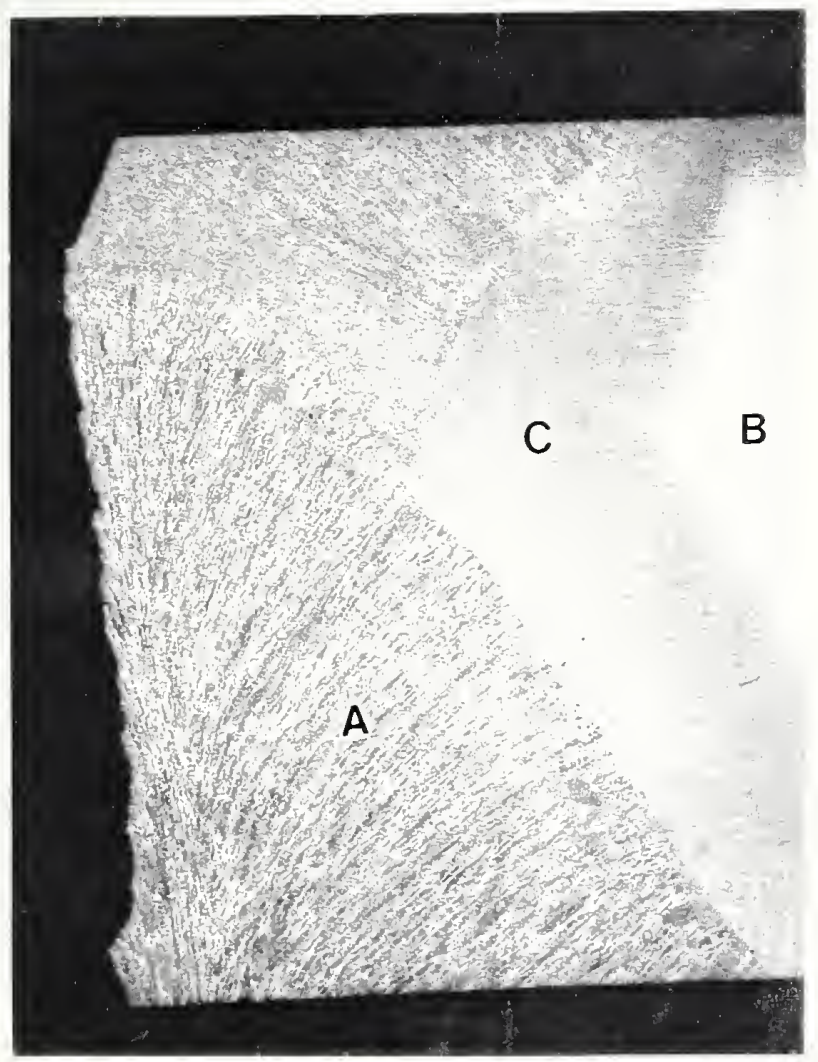

(a)

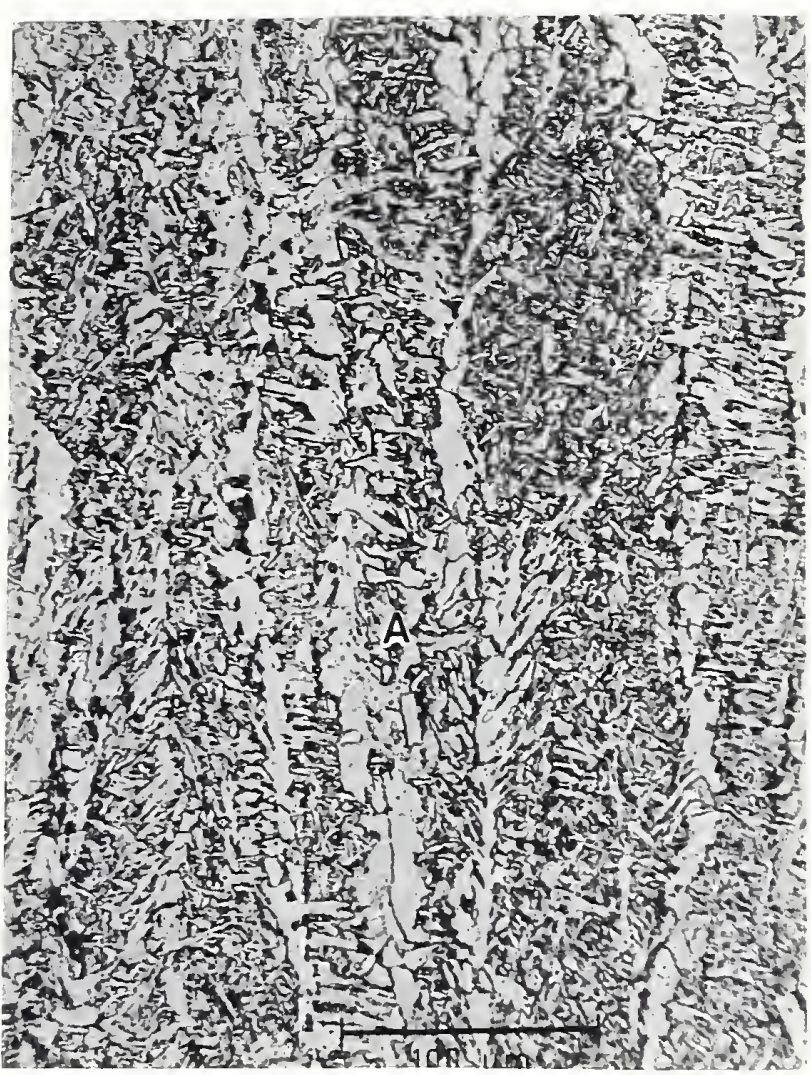

(b)

Figure 3. Photomicrographs showing the microstructure of the weld metal in specimen $1 / 2 \mathrm{~B}$. The microstructure consists of ferrite and pearlite. The weld metal is A, base metal, B; and the HAZ C. Mag: a) X6.5, b) X250 Etchant: Molybdate 



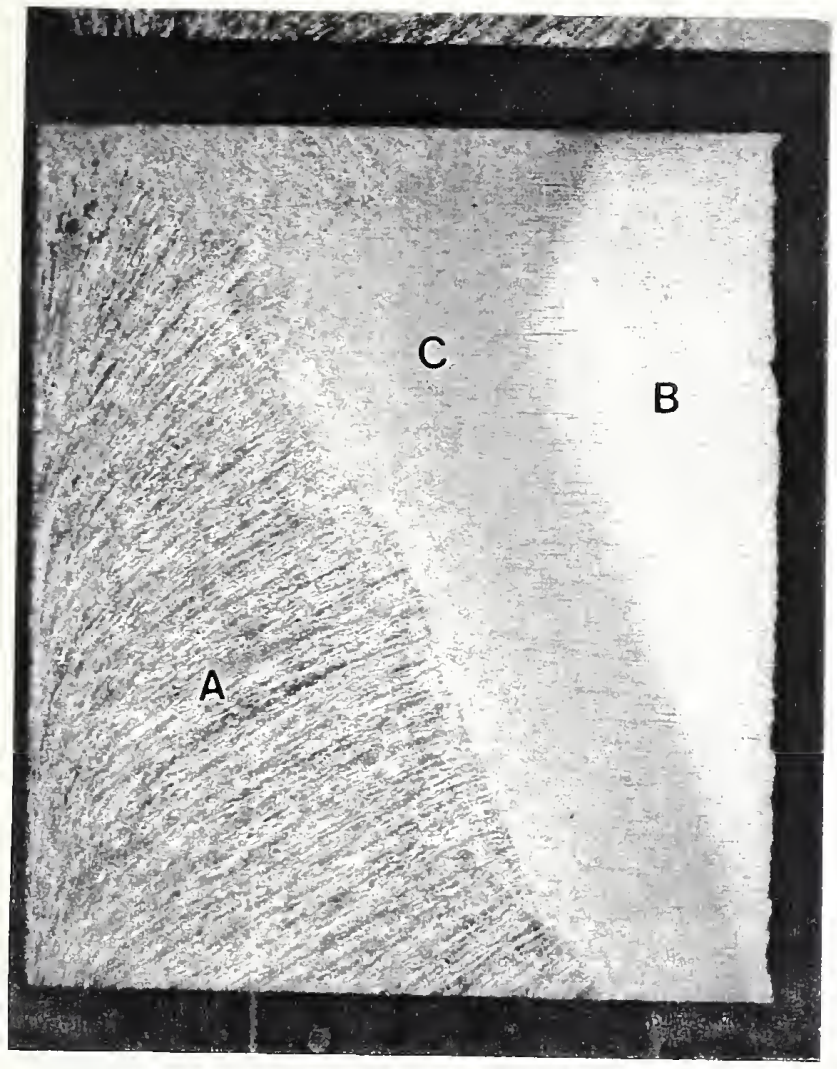

(a)

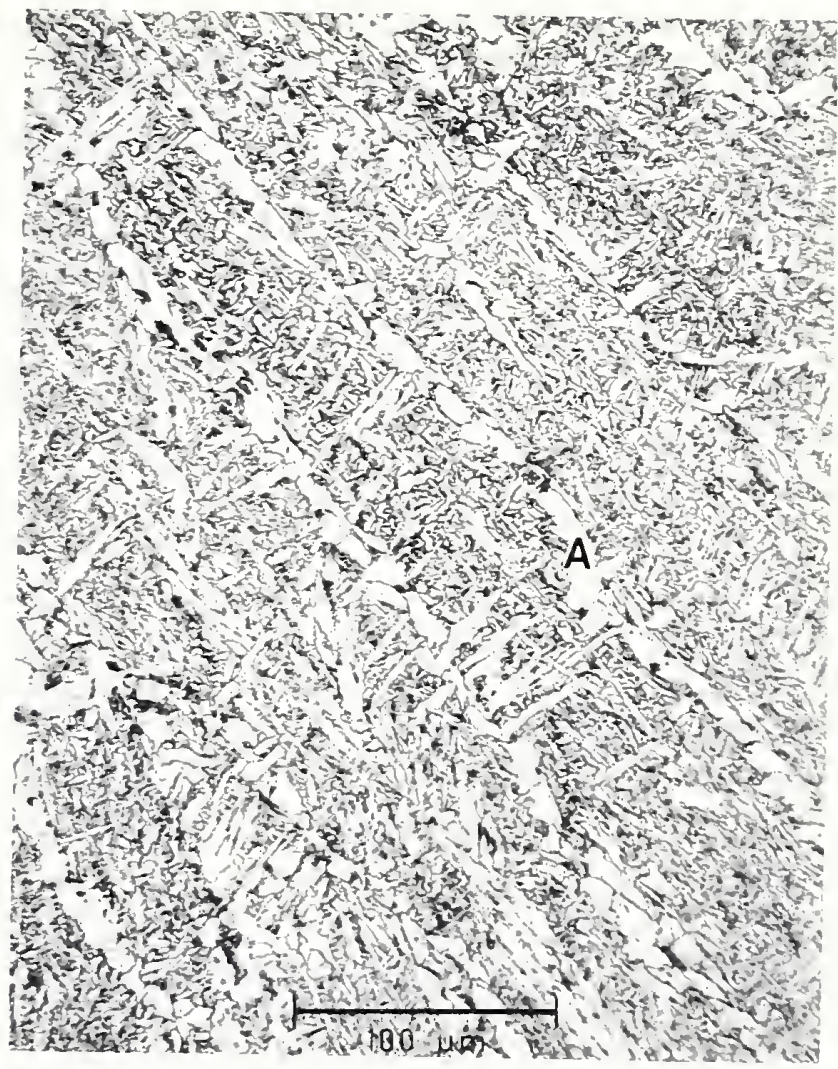

(b)

Figure 4. Photomicrographs showing the microstructure of the weld metal in specimen $1 / 2 \mathrm{C}$. The microstructure consists of ferrite and pearlite. The weld metal is $A$, base metal, B; and the HAZ C. Mag: a) X6.5, b) X250 Etchant: Molybdate 



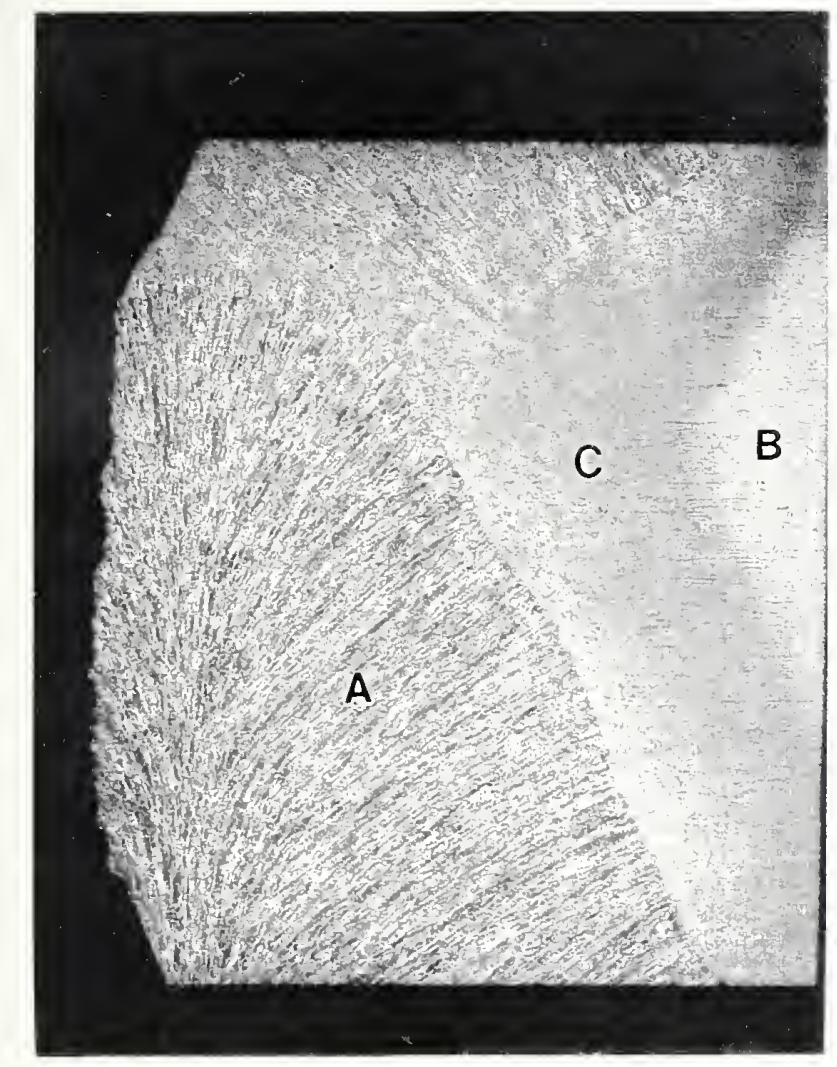

(a)

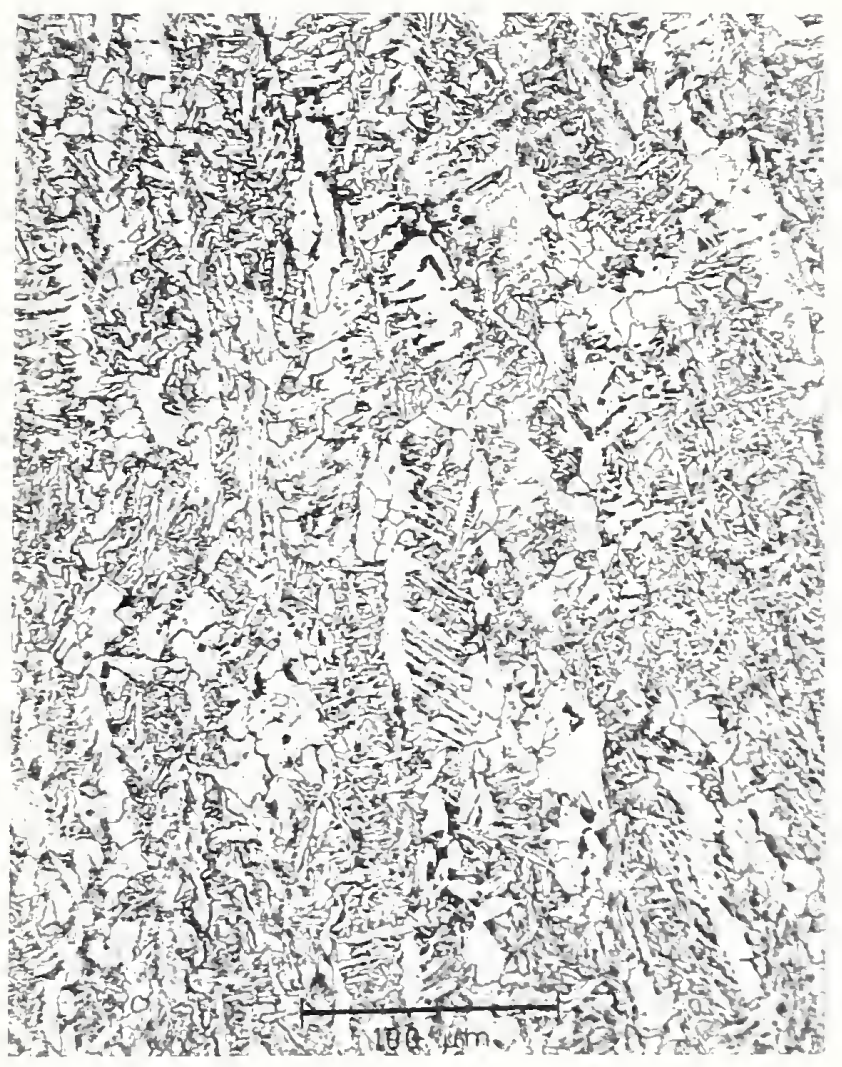

(b)

Figure 5. Photomicrographs showing the microstructure of the weld metal in specimen $1 / 2 \mathrm{D}$. The microstructure consists of ferrite and pearlite. The weld metal is $A$, base metal, B; and the HAZ C. Mag: a) X6.5, b) X250 Etchant: Molybdate 



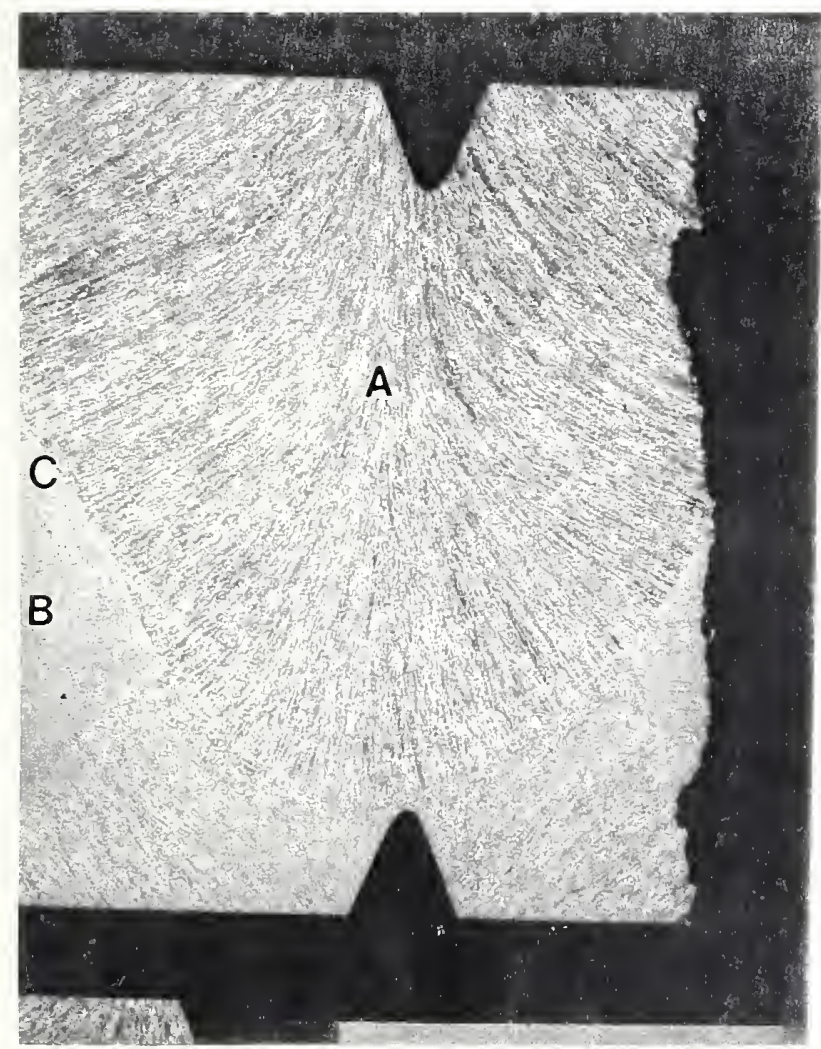

(a)

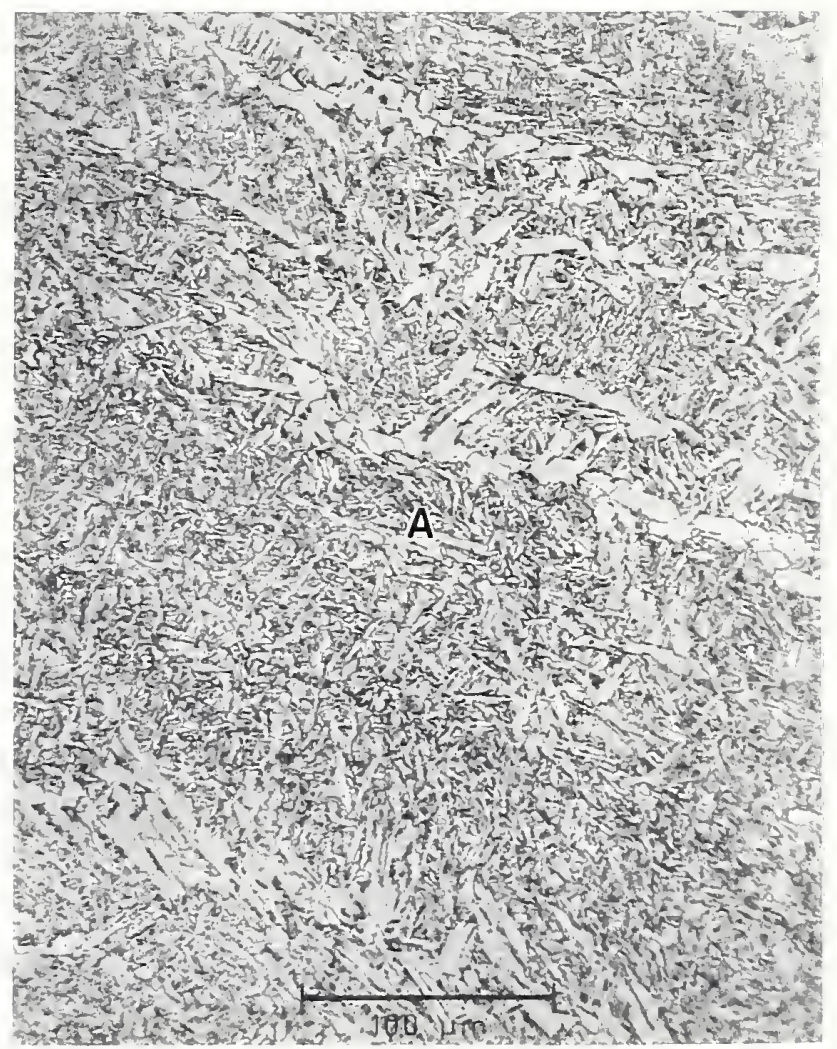

(b)

Figure 6. Photomicrographs showing the microstructure of the weld metal in specimen $1 / 2 \mathrm{E}$. The microstructure consists of ferrite and pearlite. The weld metal is A, base metal, B; and the HAZ C. Mag: a) X6.5, b) X250 Etchant: Molybdate 



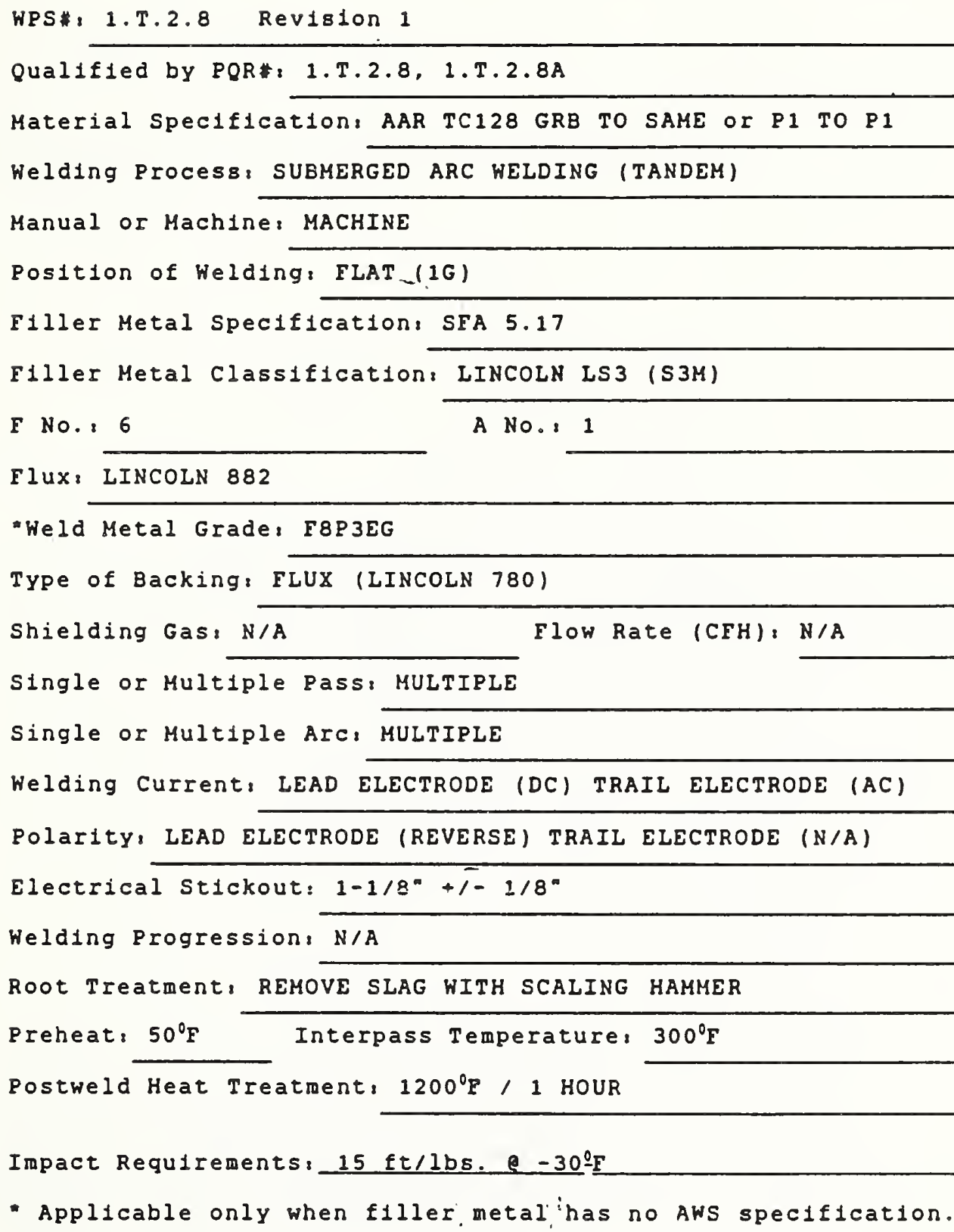




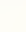


UNION TANK CAR COMPANY WPS 1.T.2.8 MAY 21, 1990

PAGE 2
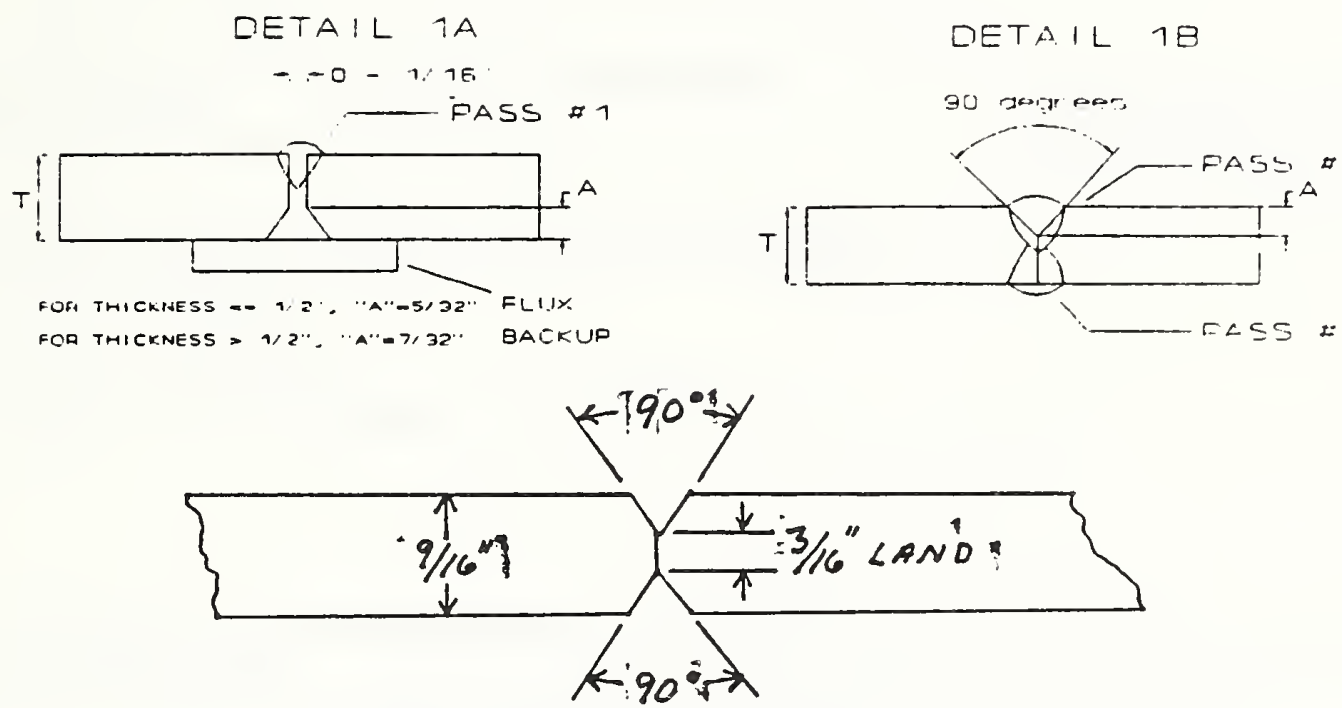

\begin{tabular}{|c|c|c|c|c|c|c|c|c|}
\hline DETAIL & $\begin{array}{l}\text { THICK - } \\
\text { INESS }\end{array}$ & $\begin{array}{l}\frac{L I}{\text { PASS }} \\
\text { NO. }\end{array}$ & $\begin{array}{l}\text { NCOLN } \\
\text { POS. }\end{array}$ & $\frac{L S-3}{\text { DIA. }}$ & $\begin{array}{l}\text { ELECTRODE } \\
\text { |AMPS }\end{array}$ & $1 / 882$ & $\begin{array}{l}\frac{\text { FLUX }}{\text { TRAVEL }} \\
\text { SPEED }\end{array}$ & |REMARKS \\
\hline $1 \mathrm{~A}$ & $7 / 16^{\circ}$ & 1 & $1 G$ & $5 / 32^{\prime \prime}$ & $600-650$ & 30 & $34-36$ & $D C$ \\
\hline $1 \mathrm{~A}$ & $7 / 16^{\prime \prime}$ & 1 & $1 G$ & $5 / 32^{\prime \prime}$ & 600 & 37 & $34-36$ & $A C$ \\
\hline 18 & $7 / 16^{\circ}$ & 2 & $1 G$ & $5 / 32^{\prime \prime}$ & 850 & $32-33$ & $34-36$ & $D C$ \\
\hline $1 B$ & $7 / 16^{\prime \prime}$ & 2 & $1 G$ & $5 / 32^{n}$ & 600 & 37 & $34-36$ & $A C$ \\
\hline $1 \AA$ & $5 / 8^{\prime \prime}$ & 1 & $1 G$ & $5 / 32 "$ & $625-675$ & 31 & 32 & DC: \\
\hline $1 \mathrm{~A}$ & $5 / 8 "$ & 1 & $1 G$ & $5 / 32 "$ & 600 & 37 & 32 & AC \\
\hline $1 B$ & $5 / 8^{\prime \prime}$ & 2 & $1 G$ & $5 / 32^{\circ}$ & 900 & 34 & 32 & $D C$ \\
\hline $1 B$ & $5 / 8 "$ & 2 & $1 G$ & $5 / 32^{\prime \prime}$ & 600 & 37 & 32 & $A C$ \\
\hline TA & $9 ! 16 \%$ & 27 & $1 G^{\mathrm{T}}$ & $5 \% 32 \pi$ & $625-67.5$ & $31=$ & $34-36$ & $D C j$ \\
\hline$-1 A-T^{2}$ & $\geq 9 / 16 \%$ & 17 & $1 G^{5}$ & $5 \longdiv { 3 2 } 2 ^ { n }$ & $600 \mathrm{~K}$ & $-37^{-1}$ & $34-36$ & $A C$ \\
\hline $1 B=2$ & $9 / 16^{n}$ & 25 & $1 G^{\circ}=$ & $5 / 32$ & 900 & -34 & ${ }^{-\cdots} 36$ & DC \\
\hline $2 B^{2}=$ & $9116^{-6}$ & $2 \%$ & $1 \mathrm{Gu}$ & $5 / 32$ & 6007 & $-37 \div$ & $\left|-36^{\cdots}\right|$ & $\mathrm{AC}^{-}$ \\
\hline
\end{tabular}



NIST-114A

(REV. 3-0)
U.S. DEPARTMENT OF COMMERCE

NATIONAL INSTITUTE OF STANDARDS AND TECHNOLOGY

\section{BIBLIOGRAPHIC DATA SHEET}

\begin{tabular}{l} 
1. MURUCATION OR AEPOAT MUMEER \\
NISTIR 4767 \\
\hline 2. PERFORMINO ORGAMIZATION REPORT NUMBER \\
3. PUEUCATION DATE \\
FEBRUARY 1992
\end{tabular}

4. TITLE AND SUBTTILE

Weld and Heat Affected Zone Crack Arrest Fracture Toughness of AAR TC128

Grade B Steel

5. AUTHOA(S)

George E. Hicho

Donald E. Harne

6. PERFORMIMG ORQANIZATION (IF JOINT OR OTHER THAN NIST, SEE INSTRUCTIOHS)

U.S. DEPARTMENT OF COMMERCE

MATIONAL INSTITUTE OF STANDARDS AND TECHNOLOQY

CATTHERSBURQ, MD 20890

9. SPONSORIMO ORCANIZATION MAME AND COMPLETE ADDRESS (STAEET, CTY, STATE, ZP)

Federal Railroad Administration

Safety Research Division

DOT/FRA ORND, Room 8305

4007 th Street, S.W., Washington, D.C. 20595

10. SUPPLEMENTAAY MOTES

N/A

11. ABSTACT (A 2OO-WORD OR LESS FACTUAL SUMMAAY OF MOST SIONIFICANT INFOAMATION. OF DOCUMENT MCUDES A SIOMIFICANT RIBUOCRAPHY OA UTERATURE SURVEY, MENTION TT HERE)

Weld and heat affected zone (HAZ) crack arrest fracture toughness were

determined for welded plates of normalized AAR TC128 grade B steel, currently

used in appropriate tank cars that carry hazardous materials. The plates were

joined under laboratory conditions and stress relieved using the recommended

Association of American Railroads (AAR) welding procedures. In the calculation

of the crack arrest fracture toughness, the yield strength at the test temper-

ature is required in the appropriate equations. Hence weld metal tensile

specimens were prepared from the joined plates and tested at temperatures

ranging from $-51^{\circ} \mathrm{C}$ to $-18^{\circ} \mathrm{C}$. Weld and $\mathrm{HAZ}$ crack arrest fracture toughness

specimens were prepared and tested at $-51^{\circ} \mathrm{C}$. Because of enhanced weld tough-

ness, it was impossible to initiate a crack in any of the weld specimens tested,

hence a crack arrest fracture toughness was not obtained. Crack arrest fracture

toughness tests were conducted on similar specimens where the crack plane was

within the HAZ. Crack arrest fracture toughness values were obtained for

specimens tested at $-51^{\circ} \mathrm{C}$ and at $-18^{\circ} \mathrm{C}$. Specimens tested at $-29^{\circ} \mathrm{C}$ were not

valid since the final crack length could not be determined. Crack arrest

fracture toughness results indicated that both the weld metal and the HAZ for

the welded normalized and stress relieved AAR TCl28 grade B steel were highly

resistant to crack initiation and possessed the ability to arrest a propagating

crack.

12. KEY WOADS (O TO 12 ENTRIES; NLPHABETICAL OADER; CAPTTLEE OMLY PROPEA MMMES; AHD SEPARATE KEY WORDS WY SEMICOLONS)

Crack arrest; Base metal; Fracture toughness; heat affected zone; steel; tank car; welds

FOR OFFICLLL DISTRIBUTION. DO NOT AEEASE TO MATIOHAL TECHMICNL INFORMATION SERVCE (MTSS).

ORDER FROM SUPERINTEMDENT OF DOCUMENTS, U.S. GOVERNMENT PRINTINO OFFICE, WASHINOTOH, DC 20402.

ORDER FAOM MATIONAL TECHNICAL INFORMATION SERVCE (MTIS), SPRIMOFIELD, VA 22161.

14. NUMBER OF PAINTED PAQES

16

15. PAICE

$\mathrm{A} 02$ 

